\title{
WHY ISLAND FEMINISM?
}

\author{
[Received March 13 ${ }^{\text {th }}$ 2017; accepted March 19th 2017 - DOI: 10.21463/shima.11.1.o6]
}

\section{Marina Karides}

University of Hawai'i at Hilo <mkarides@hawaii.edu>

\begin{abstract}
Island Studies literature rarely has engaged with feminism or queer theory to explore how gender and sexuality, as it intersects with other social forces, contour the lives of islanders and the cultural and socio-economic conditions of islands. Concurrently, feminist and queer research on islands and of islanders analyse social inequalities, sexuality, and coloniality without deliberating islandness and Island Studies research. Island feminism is offered as a synergistic perspective to enable critical analysis of the social inequalities and sexuality regimes within and across islands and the varied gendered strategies for maintaining island livelihoods and preserving island topologies.
\end{abstract}

KEYWORDS: Feminism, Island Studies, Intersectionality, Queer Theory

Gendered Islanders, Island Sexualities

Beginning in the mid-1990s, scholars, development professionals, and islanders challenged uninformed and uniform perceptions of islands and islanders that relied on tropes of isolation and backwardness used readily by urban and continental publics, a bias also evident in national and international development policy circles and among academics. In its stead, a body of "island positive" scholarship flourished, articulating rich and resistant cultural forms, organic habits of ecological sustainability, and rethinking relationships between islands and continents, their archipelagos and marine environments, and creating new typologies of islands. Driving critique and analysis in Island Studies as it came of age was its own codification and conceptualisation along with a series of case-based empirical studies on topics such as migration, tourism, artistic productions, and economic development patterned by the unique conditions of islands. Much research in the field is also dedicated to geological and ecological features of islands and their unique flora and fauna.

Largely neglected in the Island Studies literature has been critical analysis of the social inequalities and hierarchies within and across islands. Although places and spaces are gendered, oriented by sexuality regimes, class and racial hierarchies, and sculpted by coloniality and national status, Island Studies scholarship barely has considered how life and opportunities on islands and between islands are shaped by these factors. With few exceptions (see Lattas, 2014 and Barney, 2007 - both in Shima), research or theoretical consideration of how island societies construct and are shaped by gender and sexuality is almost entirely absent in journals and publications dedicated to Island Studies.

With similar indifference, feminist scholarship in geography, sociology, and other related disciplines have not considered how "islandness" or the social construction or spatial imaginary of islands guides gender and informs sexualities on islands (or not). Instead,

Shima <www.shimajournal.org> ISSN: 1834-6057 
much feminist and gender research conducted on islands (including my own) uses postcolonial or political economic critiques of gender and sexuality. In both feminist and queer research on islands there appears to be little reference to island specificities. For instance, "island woman" or "island man" is popularly used to gender, sexualise, or racialise islanders, but the geographic dimension of this phrasing, although elemental to the underlying implication, remains largely unaddressed in feminist scholarship (Karides, 2016b).

Gender, Place $\mathcal{E}$ Culture: A Journal of Feminist Geography, publishing articles on gender and/or sexuality and place, is a treasure trove for geographical explorations and articulations that account for spatial inequalities. Yet only a single publication, examining the geography of gay and lesbian clubbing and "applying the metaphors of the island archipelago from cultural geography to the gay and lesbian scene" (Cattan and Vanolo, 2014: 1158) refers to "islandness." Publications of research on islands (estimated at 165 articles, to date) in Gender, Place, and Culture make little reference to Island Studies and do not interrogate islandness as a dimension that intersects with gender, sexuality, ethnicity, or coloniality, or capitalism, themes largely relied upon in the journal, to account for uneven social-spatial conditions.

Island feminism (Karides, 2016a) is a theoretical orientation that understands "islands on their own terms" (see Baldacchino, 2008) and draws from feminisms of intersectionality, geography, and coloniality and queer theory. Whether as systems of power or the basis of identities, race, class, gender, sexuality, and nation intersect with living on and being from an island. Island feminism might facilitate a shift from an "island positive" to an "island critical" perspective within the consolidating field of Island Studies without the dated and dim rhetoric of islands as backwards.

Islands in their isolation, with their ecological particularities and their connectivity with flows of visitors (tourists, "experts," kin etc.) upholding long standing transnational social networks and parallel enduring local communities, maintain a particular set of gendered and sexual arrangements that deserve consideration by feminists, island studiers, and social scientists. An island feminist perspective could benefit future strategies for island policies, including those that address economic development and climate change, and support cultural resistance by recognising and supporting the varied gendered strategies for maintaining island livelihoods and preserving island topologies.

Launching an island feminist perspective is driven by the need to develop a conceptual orientation to the intersections of island with gender, sexuality, race, nation, and class. It includes:

a) the goal of encouraging more feminist research on island contexts that applies an Island Studies perspective;

b) studies of islandness and island societies that include feminist orientations;

c) cataloguing and documenting shifts in gender and sexuality on islands resulting from the impact of globalisation in forms such as tourism, militarism, and development; and d) an appraisal of concepts and theories of islands through the lens of feminism.

My own fieldwork on islands includes four locations of study: the Republic of Trinidad and Tobago; the Republic of Cyprus; Lesvos, Greece; and Hawai'i Island, Hawai'i (if a metaphorical definition of islands were acceptable, the city of New Orleans could be included as well). It is on the basis of these fieldwork experiences, which have focused on

Shima Volume 11 Number 12017

$-31-$ 
gender, race, and economic development, women's creative productions and strategies of economic survival, sexuality and commitment to maintaining communities and autonomous and convivial work, as well as research on feminist and queer transnational social movements, that I sketch out a framework for an island feminist perspective.

Island feminism refers to the intellectual sensibilities of island place and constructs of gender and sexuality as intertwining forces that contour the particular conditions of life economic, geographical, and ecological - and cultural and political manifestations on islands. Like most feminisms, it is action oriented, in pursuit of just and fair conditions for all beings, but is guided by specific interest in islanders' local and subaltern strategies that remain resistant to hegemonic discourses and practices of power. The enterprises, social forms, collective and environmentally attuned practices, created and lived by marginalised populations in marginalised places, or islands, are examined as a matter of organic culture, identity, and convivial economy rather than intentional mobilisation or in reaction to mainland demands. Island feminism re-appropriates the popularly narrow vision of "island women" or "island men," highlighting gender and sexual diversities and the agency, geographical awareness, resourcefulness, and forms of community of lives shaped by categories of islandness (Karides, 2016a).

The interconnectedness of islands, their colonial histories, as centres of tourism, and also with place-based movements seeking sovereignty - together with the safe-keeping of identities and cultures - are some of the particularities of island place that island scholars make visible. There is arguably a heightened sense of place that island living provides and a distinct set of opportunities for localised creative action. One of the critiques of islandness, or of phenomenologies of place generally, is that they imply a singularity of experience. Hay explains:

The most persistent criticism of place phenomenology is that it homogenizes place, seeing it as reducible to a single meaning, and ignoring structures of power and exploitation that radically change the meanings with which place is imbued as one moves between groups, classes, genders and generations. (2006: 33)

An island-centered feminist perspective may overcome concerns that place, as it is experienced, hinders recognition of difference and social constructs of inequalities. One can experience islandness as it intersects with gender and sexualities along with other social conditions. Island feminism starts with the lived experiences, challenges, and opportunities of islanders, recognising that these are constantly formed and re-formed by changes in identities and the systems of gender and sexuality, race and ethnicity, or indigeneity. Taking heed of the empiricism of islandness, and attachments to island place by those living in them, their diasporas, and by mainlanders who append themselves to islands, island feminism makes no prima facie assumption that islands are better or worse for marginalised groups but seeks to articulate the social and spatial relationships configured by them.

\section{Of Feminisms and Islands}

Originally centered on women, feminism(s) advanced globally sought to identify the narrowed opportunities, limits to social, political, and economic power, and government policies structured by gender. Distinct schools of feminist thought, including liberal,

Shima Volume 11 Number 12017

-32 - 
Marxist, and socialist feminists, expanded in the global north during the first part of the 2oth Century focused on constraints faced by women. Radical feminism, introduced in the 1960 s, shaping women's protests of the period, drew attention to patriarchy as a system of power that controls women's bodies. Considered the "second wave" of feminism, radical feminism highlights rape and sexual abuse within households, media and the objectification of women, and sexual harassment in the workplace, suggesting that ideological and cultural repression are more insidious than the political and economic conditions women face.

It was black women in the US, many who were active in both feminist and civil rights movements, that first identified the inability of feminist theorising to address the diverse experience of women, challenging "woman" as a categorical condition. Black feminist thought (Hill-Collins, 1991) reoriented feminist perspectives forcing the exploration and appreciation of the intersectionality of gender, race, and class. In other words, opportunities and identities are not only gendered but, simultaneously, raced and classed. Now referred to as intersectional feminism, the acceptance that nodes of inequality such as race, class, and gender are mutually reinforcing, shaping livelihoods, culture, and identities and structuring institutions and organisations is currently at the fore of feminist thought (Choo and Ferree, 2010).

As intersectional feminism grappled with the inseparability of social forms within national contexts, post-colonial feminism advanced in relation to the global economic restructuring occurring through the 1980s. Building on Edward Said's (1978) enunciation of the "social construction of the other" as an organising principle of imperialism, post-colonial feminism captures the significance of global hierarchy among nations and races, while emphasising the centrality of gender to the world system. Postcolonial feminism also brought forth the subaltern agency of women in the global south (see Lewis and Mills [eds], 1999), focusing on the many ways poor and low-income women in these regions sustained their families, communities, and culture. Postcolonial feminism isolated and denounced "western" feminist scholarship that defined the lives of global south women by their oppression, as a singular condition with an implied superiority of the global north, and with limited regard or inquiry into these women's forms of agency and resistance (Mohanty, 1984; Briggs, 2003).

Indigenous feminisms also emerged in the 1990s, documenting the experiences of native, aboriginal, and indigenous communities and extending postcolonial analyses of patriarchy and coloniality's interdependence. Led exclusively by men, colonial incursions on native lands contrasted with the political and social leadership of many indigenous communities that included multiple genders. Enforcing colonial control required the assertion of patriarchal privilege to the detriment of indigenous principles of gender as "complimentary" rather than "dichotomous" (Tsosie, 2011). To address the legacy of patriarchal coloniality, indigenous feminisms are characterised by proactive responsibilities to one's community and kin, retaining and renewing culture and traditions, and protecting and relating to ones ancestral lands (Anderson, 2011). Indigenous feminist approaches guide island feminism, not only because of the numerous indigenous communities on islands, but also the historical practices of islanders including the retention of island communities and culture, often the undertaking of women, and a social orientation guided by the natural environment (Hayward, 2012; Suwa, 2007).

Shima Volume 11 Number 12017

$-33-$ 


\section{Queer Islanders}

Finally, queer theory is indispensable to an island feminism. Queer theory, another result of the renaissance of gender and sexualities conceptualisations in the 1990s, is a discreet school of thought, engaged with post-structuralism and feminism. Defying the existence of sexual and gender binaries (ie gay/straight, woman/man), queer theory critiques sexuality regimes that construct sexual identities, normalising and marginalising some groups while hindering or denying a wide range of sexual expressions (Butler, 1990). Queer theory not only examines how social power influences and limits sexuality and sexual expressions but how groups and individuals challenge and play with these constructs.

For instance, in the pre-contact Pacific, non-binary expressions of gender and sexuality were customary and, in many instances, revered until the arrival of British imperialists and US missionaries imposed the patriarchal logic of their gender and sexuality regimes. Academic study of the diverse and fluid practices of gender and sexuality in the Pacific (Elliston, 2002; Besnier and Alexeyeff, 2014), in the Caribbean (King, 2014), and the Greek islands prior to the Byzantine Empire (Snyder, 1997; Hubbard 2003), have showcased a diversity of sexuality and gender orientations which could be further probed with an island studies perspective. On the other hand, because of island particularities, islanders can harbor virulent forms of homophobia, fueled by coloniality and religion (Cowell, 2011), which also could be well analysed by a queer analysis molded by island studies.

\section{Uses of Island Feminism}

Together these strains of contemporary feminism: intersectional, post-colonial, and indigenous, and queer theory are sourced for theorising island feminism. Adding islandness as a socio-ecological quality that intersects with other social forces creates an opening to evaluate inequity and diversity on and around islands. Islandness, as well aquapelagic (Hayward, 2012) or archipelagic (Stratford et al, 2011) positionalities, becomes a facet of intersectional analysis. One clear-cut example for the applicability of island feminism is addressing domestic violence in insular communities. In continental contexts, most domestic violence shelters remain hidden but this has proven to be a much greater challenge and an unlikely occurrence in smaller or more rural islands. An island feminist approach to issues of domestic violence on islands could be applied to determine intersections of insularity, gender, and criminal justice to support victims of domestic violence on islands.

An island feminism approach is especially advantageous for exploring the sexualised constructs of islands (Briggs, 2003; Sheller, 2003; Elliston, 2002) and islanders (Kempadoo, 1999; Philips, 1999; Zinovieff, 1987). Sexuality and gender often frames rhetoric and images of island tourism relying on islandness as a foundation of otherness, possibly in conjunction with coloniality or economic marginality. My recent paper on sex tourism by mostly white, economically privileged continental women who seek affairs with men in Indonesia, the Anglophone Caribbean, and Greek islands, argues that gender intersects not only with economic privilege but with constructs of islands as havens and stereotypes of island men (Karides, 2016b).

I also have applied island feminism to make sense of island women's economic practices (Karides, 2016a). This includes collective forms of economy such as cooperatives and locally 
focused small scale enterprises rooted in logics of ecological sustainability. Generally, grassroots economic forms on islands contrast with the hegemonic discourses of development emanating from continental thought (McCall, 1994) and could steer the globally expanding efforts towards local economies. Island communities' commitment to cultural resistance and the nurturance of ecological resources often determine their economic choices but this should be examined as they intersect with class, gender, race, indigeneity, or ethnicity, and economic opportunities.

The application of island feminism tackles the resistance of islanders to external influences as a measure for sustaining local culture. At times, development programs with continental bias or groups of mainland transplants initiate strategies or develop policies on islands that counter a cultivated sense of islandness, often characterised by communality and informality. The "othering" of islanders is a fruitful dimension for post-colonial analytics that is distinctly qualifiable, perceived by islanders, often when engaging with continental tourists, and identifiable by Island Studies scholars. By unraveling how islandness interweaves with other factors, such as coloniality, race, or gender, we might better grasp the multiplicities of island encounters.

In some instances, adhering to embedded beliefs and practices on islands means clinging to hierarchies around race, class, and gender and continuing patterns of discrimination. In others, rather recently imported socially and economically unjust arrangements, such as those tied to neo-liberalism, or older ones rooted in imperialism, are defended as "local" or "island ways" to explain persistent inequities and resist progressive change. Island feminism, with an emphasis on systems of powers and practices of resistance in island place, can be constructive for discerning how islandness can simultaneously be harnessed for retaining culture and supporting local knowledges, as a basis of cosmopolitanism, and to legitimate unfair and unequal treatment. Unraveling island cultures through an island feminism lens might broaden approaches to research and increase opportunities for islanders that historically have been discriminated or marginalised, improving island life overall.

Finally by engaging with island feminism, island scholars could deepen theorisation of island phenomena. In a recent article on the ni-Vanuatu women's performance of "water music," the author simply accepts the evaluation by some of its practitioners as it being "a woman's thing" (Dick, 397: 2014). Without further discussion of ni-Vanuatu women's economic concerns or the tensions between indigenous Wantok traditions of matrilineality and the patrilineal imposed by Christianity and coloniality (Thomas, 2013), the study of island tourism and Vanuatu cultural production loses an opportunity for a more provoking analysis. Particularly since the "liquid percussion practice" of ni-Vanuatu women has been employed to elucidate conceptions of "aquapelagic assemblages" (Hayward, 2012, 2014), illumination of gender and sexuality in the formation of social identities of groups tied to "aquatic spaces," could widen the dimensions of aquapelagism as well as other island concepts. The "ama," "umichi," or "kaito," the women divers of Japan, an ancient tradition of livelihood and a modern one embedded in commercialism and tourism, is another illustration of how island feminism could be applied empirically to the benefit of both the island and feminist imagination. 
Why Now?

Human geography has identified how space is constitutional to social relations and how cultures and economies shape space and place. The introduction of gender into the discipline was carved out by feminists, essentially highlighting how the organisation of place constrained women (Massey, 1994; Rose, 1993; McDowell, 1999) and revealing "that space is gendered and gendering has a profound consequences for women" (Doan, 2010: 1). Eventually a broader elaboration of gender, sexuality, and space evolved. As GibsonGraham explains:

\begin{abstract}
A feminist spatiality embraces not only a politics of ubiquity (its global manifestation), but a politics of place (its localization in places created, strengthened, defended, augmented, and transformed by women). Feminism is the politics of becoming in a place. In this admittedly stylized rendering, feminism is not about the category "woman" or identity per se, but about subjects and places. It is a politics of becoming in place. (2006: xxiv)
\end{abstract}

Feminist human geography presently attends to the production of masculinities (Berg and Longhurst, 2010), hetero-normative domination or the queering of hetero-normative spaces (ie Talburt and Matus, 2014; Doan, 2007), and broader evaluations of gender and space. Yet to reiterate, islandness and gender or sexualities hardly have been conceived together, as intersections of inequalities, for informing the making of island place or the retention of island cultures, or appreciating how islanders experience continents.

Having sculpted its own spatial frame of analysis, with a mounting mass of case studies, Island Studies is poised to critically explore social relations and the inequalities rendered and obstructed by island place, and support the forward movement of islands and islanders as they contend with tourism, climate change, and the retention of populations and identities. As articulated here, island feminism is one potential prospect for an island critical perspective that pulls from the parametric and cultural articulations of Island Studies and the recent evolutions of feminisms and queer theory. Island feminism can account for the very different experience of islanders, due to gender, sexuality, race and/or ethnicity, indigeneity, class, and other intersections, across islands and in the same island place.

\footnotetext{
Acknowledgements:

Maholo to the anonymous reviewer for "her" comments and addendum and University of Hawai'i Hilo students enrolled in Island Feminism (Fall 2015) and Feminist Social Theory (Spring 2016).
}

\title{
BIBLIOGRAPHY
}

Anderson, K (2011) 'Affirmations of an Indigenous Feminist' in Suzack, C, Huhndorf S, Perrault J, and Barman J (eds) Indigenous Women and Feminism: Politics, Activism, Culture, Vancouver: University of British Columbia Press: 81-91

Baldacchino, G (2008) 'Studying Islands: On Whose Terms? Some Epistemological and Methodological Challenges to the Pursuit of Island Studies', Island Studies Journal v3 n1: 3756

Shima Volume 11 Number 12017

$-36-$ 


\section{Karides: Why Island Feminism?}

Barney, K (2007) 'On the Margins: Torres Strait islander women performing contemporary music', Shima v2 n1: 70-9o

Berg, L.D and Longhurst, R (2003) 'Placing Masculinities and Geography', Gender, Place E Culture: A Journal of Feminist Geography v10 n4: 351-36o

Besnier, N and Alexeyeff, K (eds) (2014) Gender on the Edge: Transgender, Gay, and Other Pacific Islanders, Honolulu: University of Hawai'i Press

Briggs, L (2003) Reproducing Empire: Race, Sex, Science, and U.S. Imperialism in Puerto Rico, Los Angeles: University of California Press

Butler, J (1990) Gender Troubles: Feminism and the Subversion of Identity, New York: Taylor and Francis

Cattan, N and Vanolo, A (2011) 'Gay and Lesbian Emotional Geographies of Clubbing: reflections from Paris and Turin', Gender, Place, and Culture: A Journal of Feminist Geography v21 n9: 1158-1175

Choo, H.Y and Freree, M (2010) 'Practicing Intersectionality in Sociological Research: A Critical Analysis of Inclusions, Interactions, and Institutions in the Study of Inequalities', Sociological Theory v28 n2: 129-149

Cowell N.M (2011) 'Public Discourse, Popular Culture and Attitudes Towards Homosexuals in Jamaica', Social and Economic Studies v6o nı: 31-6o

Dayal, S (2008) 'By Way of an Afterword' in Hawley, J (ed) Post-colonial Queer: theoretical intersections, Albany: State University of New York Press: 305-323

Dick, T (2105) 'Chorographing The Vanuatu Aquapelago', Shima v9 n2: 1-22

Doan, P.L (2010) 'The Tyranny of Gendered Space - reflections from beyond the gender dichotomy', Gender, Place, and Culture: A Journal of Feminist Geography v17 n5: 635-654

Elliston, D (2002) 'Anthropology's Queer Future: Feminist Lessons from Tahiti', in Lewin, E and Leap, W (eds) Out in Theory: The Emergence of Lesbian and Gay Anthropology, Champaign: University of Illinois Press: 287-315

Gibson-Graham, J.K (2006) The End of Capitalism (As We Knew It): A Feminist Critique of Political Economy, Oxford and Cambridge: Blackwell Publishers

Hau'ofa, E (1993) 'Our Sea of Islands', in Hau'ofa, E, Naidu, V and Waddell, E (eds) In A New Oceania: Rediscovering our Sea of Islands, Suva: University of the South Pacific in association with Beake House: 2-19

Hawley, J.C (2001) 'Introduction' in Hawley, J.C (ed) Post-colonial, Queer: Theoretical Intersections, Albany: State University of New York Press: 1-18

Hay, P (2006) 'A Phenomology of Islands', Island Studies Journal vı nı: 19-42

Shima Volume 11 Number 12017

-37 - 


\section{Karides: Why Island Feminism?}

Hayward, P (2012) 'Aquapelagos and aquapelagic assemblages', Shima v6 nı: 1-11

----- (2014) 'Sounding the Aquapelago: The cultural-environmental context of ni-Vanuatu women's liquid percussion performance', Perfect Beat v15 n2: 113-127

Hill-Collins, P (1991) Black Feminist Thought: Knowledge, Consciousness, and the Politics of Empowerment, New York and London: Routledge

Hubbard T. K (2003) Homosexuality in Greece and Rome: A Sourcebook of Basic Document, Berekely: University of California Press

Karides, M (2012) 'Local Utopia as Unobtrusive Resistance: The Greek Village MicroEconomy', Journal of World Systems Research v18 n2: 151-156

----- (2016a) 'An Island Feminism Perspective: Convivial Economics and the Women's Cooperatives of Lesvos', in Stratford, E (ed) Island Geographies: Essays and Conversations, Mew York: Routledge: 78-96

----- (2016b) 'Empiricizing Island Feminism: Constructs of Island Masculinities and Sex Tourism', paper present at the International Small Island Studies Association 'Islands of the World XIV' Conference in Mytilini, Lesvos, Greece

Kempadoo, K (1999) (ed) Sun, Sex, and Gold: Tourism and Sex Work in the Caribbean, Lanham: Rowman and Littlefield

King R.S (2014) Transgressive Sexualities in the Caribbean Imagination, Gainesville: University Press of Florida

Lattas, J (2014) 'Queer Sovereignty: the gay and lesbian kingdom of the Coral Sea Islands', Shima v8 n1: 59-71

Lewis, R and Mills, S (2003) (eds) Feminist Postcolonial Theory: A Reader, Edinburgh: Edinburgh University Press

McCall, G (1994) 'Nissology: The Study of Islands', Journal of the Pacific Society v17 n2-3: 114

McDowell, L (1999) Gender, Identity, and Place: Understanding Feminist Geographies, Minneapolis: University of Minnesota

Massey, D (1994) Space, Place, and Gender, Minneapolis: University of Minnesota Press

Mohanty, C (1984) 'Under Western Eyes: Feminist Scholarship and Colonial Discourses' Boundary v12/13 n3/4: 333-358

Philips, J.L (1999) 'Tourist-Oriented Prostitution in Barbados: The Case of the Beach Boy and the White Female Tourist', in Kempadoo, K (ed) Sun, Sex, and Gold: Tourism and Sex Work in the Caribbean, Lanham: Rowman and Littlefield: 183-200

Rose, G (1993) Feminism \& Geography: The Limits of Geographical Knowledge, Minneapolis: University of Minnesota Press

Shima Volume 11 Number 12017

-38 - 


\section{Karides: Why Island Feminism?}

Said, E.W (1978) Orientalism, London: Penguin Books

Sheller, M (2003) Consuming the Caribbean: From Arawaks to Zombies, New York and London: Routledge

Snyder J.M (1997) Lesbian Desire in the Lyrics of Sappho, New York: Columbia University Press

Stratford, E, Baldacchino, G, McMahon, E, Farbotko, C and Harwood, A (2011) 'Envisioning the Archipelago', Island Studies Journal v6 n2: 113-130

Suwa, J (2007) 'The Spaces of Shima' Shima vı nı: 6-14

Talburt, S and Matus, C (2014) 'Confusing the Grid; spatiotemporalities, queer imaginaries, and movement', Gender, Place, and Culture: A Journal of Feminist Geography v21 n6: 785-801

Tsosie, R (2011) 'Native Women and Leadership: An Ethics of Culture and Relationship', in Suzack, C, Huhndorf, S, Perrault, J and Barman, J (eds) Indigenous Women and Feminism: Politics, Activism, Culture, Vancouver: University of British Columbia Press: 29-42

Zinovieff, S (1991) 'Hunters and Hunted: Kamaki and the ambiguities of sexual predation in a Greek Town', in Loizos, P and Papataxiarchis, E (eds) Contested Identities: Gender and Kinship in Modern Greece, Princeton: Princeton University Press: 203-220 